\title{
13
}

\section{Cultural heritage and its performative modalities: Imagining the Nino Konis Santana National Park in East Timor}

\author{
Andrew McWilliam, The Australian National University, Canberra, Australia
}

\section{Introduction}

In East Timor the struggle for national independence was hard won and required a unity of shared purpose from the broad community of resistance. Part of the task of sustaining that sense of unity in the post-independence Democratic Republic of Timor Leste is the imaginative work of commemorative symbols that enjoin citizens within a common narrative of nation. My paper looks at one such commemorative symbol: the establishment in $2007^{1}$ of the Nino Konis Santana National Park in the densely forested eastern portion of the island. The legislation creates the first National Park in an independent Timor-Leste and carries with it a complex range of associations, expectations and attributions. Within that complex, I am interested in the questions it raises around what I call the competing performative modalities of connection and significance. The tension in this case arises between state-making projects of institutional governance acting in the wider public interest and the more prosaic place-making projects of customary communities' resident within the National Park itself from which they derive household sustenance and material needs.

Towards an understanding of this mutual entanglement of state and local sensibilities, I wish to draw upon two inter-related analytical perspectives. One develops a useful distinction highlighted by anthropologist, Janet Hoskins, between history and heritage as ideal types of contrasting interpretations of the past. In her view: '[T] he historical past is a linear time line, with non-repeating events by individual actors discontinuous with the present.' This historical consciousness: 'creates a finished chapter that may be reopened and reread but not re-written.' In contrast the heritage of the past, rather than a line of unique occurrences, 'forms an array of established and shared sequences that may be instantiated in various new and transformed ways. People with a cultural heritage consciousness see themselves acting in the place of ancestors, reproducing their practices and continuing a pattern of timeless reciprocities' (Hoskins 1993). The distinction here between history and heritage is not mutually exclusive however, and people may sustain both forms of orientations towards the past, but it is equally evident that in doing so they induce very different kinds of understandings about the ontology of past events. ${ }^{2}$

\footnotetext{
1 Legislation establishing the creation of the NKSNP was formally enacted in the dying days of the Fretilin government (3 August 2007) under the signature of the Minister of Agriculture Fisheries and Forestry at the time.

2 The distinction between history and heritage has of course been subject to much debate and definition (e.g. see Harvey 2001 for a discussion of the history of heritage). Although narrower in its formulation than other representations of the debate, I find Hoskins' take on the matter to be particularly instructive in terms of the material at hand. There are also resonances with other views such as those of Lowenthal who has written extensively on the changing role and perceptions of the past in shaping contemporary lives (e.g. Lowenthal 1985). His observation that the 'creed of heritage answers needs for ritual devotion', rather than the facts of the matter, is consistent with the distinction Hoskins seeks to make (1998).
} 
I would like to compare and complement this view with a second analytical perspective taken from another anthropologist, Charles Zerner who writes of the 'performative modalities of customary attachments to particular local environments' (2003:3). These modalities can include poetics and mythologies of connection, ecological knowledge of plants and animals and the various material and ideational attachments to place reproduced by local communities over time. As diverse forms of knowledge and practice they work to authorise and legitimate local attachments to place in customary terms. Characteristically however, from the perspective of state regulatory agencies, local knowledge in this form confronts what Zerner calls the 'challenge of translation'. This is the problem of translating these diverse cultural performative modalities into legible forms recognised by state regulatory institutions as 'legal rights', or otherwise 'legally valid representations of entitlement that still maintain their integrity and sensibility' (Zerner 2003). Unfortunately the history of these attempts, where they have been recognised as relevant issues by governments, has been a poor one and frequently resulted in the denial or erasure of customary entitlements in the interests of 'the wider public good' (see McWilliam 2007); in Zerner's terms, their distinctive logics, metaphors and modalities defined away (2003:17).

In the following discussion I seek to adapt these two analytical approaches to argue that the contemporary development of the Nino Konis Santana National Park is part of an imaginative and interpretive struggle over the commemorative shape of national history in the context of a living emplaced local heritage.

\section{Inscribing natural values}

Following its ratification, the public proclamation of the Nino Konis Santana National Park (NKSNP) in August 2008 was enacted with much ceremonial protocol and fanfare within the Park itself. The attendance of politicians, international dignitaries, media, armed security forces and government officials along with invited groups of local Fataluku villagers cloaked the event with the symbolic authority of the state, while the then president, Xanana Gusmao himself, arrived by helicopter and was greeted with traditional dancing and ritual speech.

The Park covers a terrestrial area of some $1236 \mathrm{~km}^{2}$ in the most easterly district of East Timor known as Lautem. It includes a similarly extensive area of coastal waters and fringing coral reefs $\left(556 \mathrm{~km}^{2}\right)$ that forms a designated protected marine zone. The Park incorporates Lake Ira lalaru, the largest freshwater lake on the island of Timor and the densely forested Pai $\mathrm{Cao}^{3}$ mountain range on its southern flanks. The extensive and largely unpopulated stretches of monsoon and evergreen canopy rainforest on its northern and southern reaches are integral features and form a unique zone of lowland tropical rainforest.

In recognition of the long history of settlement in the region by Fataluku-speaking local communities, the government has sought to follow the conventions of the International Union for the Conservation of Nature (IUCN) to establish the National Park in a way consistent with principles of IUCN Conservation Level 5. This category is one that intentionally recognises the role of human interaction in the reproduction of environmental values, and so allows for multipurpose activities and the development needs of resident Fataluku villages within defined zones of activity. Specifically the intent of the government in establishing the initiative was to manage the Park as an internationally recognised protected area where the traditional interactions of people and nature are maintained in a way that protects the environment' (MAFP 2006). As the boundaries of the Park incorporate the resident populations and lands of six Timorese villages (suku), ${ }^{4}$ it is evident that much of the area will be zoned for settlements and agriculture, but there are also plans for protected and no-take areas.

3 In Fataluku orthography the letter c is pronounced 'ch'. Hence, Pai cao or 'pig's head'.

4 They comprise the villages of Bauro, Poros, Mehara, Tutuala, Muapitine and Lorehe 1, with a total resident population of around 15,000 (see census 2004). 
The creation of the National Park has been many years in the making and represents the sustained efforts, aspirations and commitment of many Timorese championing the cause both within and outside government. There are two key aspects of the Park that arguably justified its creation from the collective perspective of the National Government. The first of these elements is the rich complexity of natural values and high biodiversity flora and faunal species found in the park area. This has been confirmed in numerous surveys of its forested and marine environments that have consistently identified important endemic and endangered species. In fact, regard for the natural environmental values has its origins in Portuguese colonial rule with the establishment of the Colonial Forestry Service in 1924 (Cardoso 1933). Admittedly this was driven more by interests in commercial grade timber supply than its unique biodiversity, but the seeds of a forestry reserve system was established at the time and included a silviculture research station in the dense lowland canopy forests of Lorehe and Paicao. ${ }^{5}$

Recognition of the need to conserve the remaining forest reserves in East Timor emerged during the post-war colonial period. Silva (1956:89) for example, called for the protection of primary forest across the region as a matter of urgent necessity, but it was during Indonesian rule after 1975 that the forested Pai cao mountains were designated as a conservation reserve (Cagar alam). In 1993 under a Biodiversity Action Plan for Indonesia, the region was recognised as one of 40 representative areas. Finally, during the UN Transitional Administration in East Timor (Untaet 1999-2002) the eastern part of Lautem was legislated as one of 17 so-called, Wild Protected Areas which sought to conserve its impressive environmental qualities and build a network of protected environmental zones across the country (UNTAET 19/2000) (see McWilliam 2003). The present formulation of the region as a high quality biodiverse land and seascape thus reinforces a lengthy history of state inscriptions and authorised recognition of core natural values.

\section{Landscapes of resistance}

The second important basis for declaring the National Park is its historical and symbolic significance in the heroic struggle for national independence and there are at least three influential factors that might be seen as central elements in this consideration. The first is the name itself. Nino Konis Santana (1958-1998) was a local Fataluku school teacher from Tutuala who joined the armed struggle and rose through the ranks to become the leader of Timorese armed resistance known as Falintil ${ }^{6}$ between 1993 until his untimely death in 1998. The name of the Park commemorates his sacrifice and resonates with local aspirations for the recognition of Fataluku contributions to independence while speaking symbolically to the suffering of the nation as a whole.

The forested region with its tangled jungle and rugged karst topography also provided refuge and protection to another former guerrilla leader, Xanana Gusmao especially during the dark days of the late 1970s following the near destruction of the Falintil forces as a result of the Indonesian encirclement and bombing campaign in the Matebian mountains in neighbouring Baucau district (Budiarjo et al. 1984). Xanana and his supporters spent years living in the forests provisioned and protected by local Fataluku village sympathisers who risked reprisals and worse in their efforts to maintain the small groups of guerilla combatants. During the early 1980s while Xanana lived under secluded protection in the village of Mehara, he is credited with formulating the clandestine resistance strategy and the shift to a largely urban based civilian resistance struggle that ultimately proved unstoppable.

\footnotetext{
5 The lucrative trade in sandalwood that attracted Portuguese and other interests to Timor from the late sixteenth century by this time was much degraded and in 1926 export of the fragrant timber was officially banned. Sandalwood is a prominent endemic species in the park, particularly in the fallowed garden lands of the monsoon rainforest that covers much of the north east coast and hinterland. It is not a feature of the dense wet rainforests of the Paicao ranges.

6 From the Portuguese, Forças Amadas da Libertação Nacional de Timor-Leste.
} 
The third and related factor is that the forested eastern region remained one of the key sites of continuing armed resistance against the Indonesian military throughout the 24 years of occupation (see also Pannell and O'Connor 2005). For this reason the area was known in the lingua franca, Tetun, as the rai funu nafatin ('the land of continuous war'). In this heroic historical perspective then the Park commemorates the forest as a landscape of warfare and struggle; one inscribed with markers and memories of conflict and suffering, hideouts and refuges, secret trails and ambush sites. As a 'landscape of memory' (Hviding and Bayliss Smith 2000) the Park offers a scenic living monument to national liberation and one which Fataluku residents recognise as their specific contribution to the 'historical record'.

Taken together these two influential guiding values, high biodiversity and resistance history, certainly find some support among the resident local Fataluku communities. Many have been active in the events it commemorates and make use of the bio-diversity it celebrates. But if recent resistance history represents an important episode in their lives, it is only one chapter in generations of connection and reproduction of the forested landscape. As a proposed conservation park with plans for ecotourism and restrictive protections over high value portions of the forest and reefs zones, many local people express a degree of ambivalence and anxiety over the direction of future government regulatory management.

\section{Cultural landscapes and unsettling histories}

One of the ironies of the values attributed to the National Park through its state authorised creation' is that while the region has long been recognised for its natural biodiversity, it is by no means a pristine wilderness or primary canopy rainforest. On the contrary, while pockets of primary rainforest survive in steep ravines or isolated peaks, the broader park reflects a highly enculturated mosaic of aged and long fallow regrowth, of former swidden gardens and settlement sites (McWilliam 2007). The forest floor is littered with the remnants of past occupation by former Fataluku households and communities. Old stone garden walls, aged coconut palms, crumbling evidence of house foundations as well as numerous massive stone walled fortifications on hilltops with their old stone graves and pottery shards providing rich evidence of extensive past occupation. In reality the now unsettled areas of the National Park and its forested interior owe more to long term processes of population displacement than any active processes of nature conservation.

The process of displacement has its origins in early twentieth century policies of the Portuguese Colonial Government that sought administrative enclosure by drawing the scattered forest Fataluku into more concentrated residential clusters. ${ }^{7}$ The movement was a gradual one, disrupted by the brief Japanese occupation of the island during World War II, but eventually it saw dozens of small residential communities in the forested northern and southern zones of the park permanently relocated to the main roads or to main towns where they were closer to development services and state regulatory surveillance and where, for the most part, they still reside. Places like Loequeiro, Poros, Somoco, Bauro, Asalaino and Sepaerara now cluster along the Tutuala road, but previously occupied residential sites in the northern forested plateau. Similarly, the whole of the settled highlands of Nari (Planalto de Nari in the central north) were emptied out and its residents relocated to contemporary roadside settlements near the northern coast. They include: Pairara, Punu, Moro, Ipairira and Soekili. In the southern forested zone, relocated settlements include, Ira Ara, Lere Loho, Pehe Fitu, Lupuloho, Muapitine, Veterr, and Vero among others, and in many cases are the result

\footnotetext{
7 This heightened period of Portuguese military effort was part of a general campaign to extend their authority and effective control across the whole of the territory. It mirrored the kind of military-backed pacification wars promulgated by the Colonial Dutch government across the eastern islands at much the same time and directed to similar ends. We might view the displacement process of these and later Indonesian government programs, as part of a characteristic strategy of states to impose structures of surveillance and economic development as part of a territorial impulse for encompassment and control (see for example Scott 1998; Li 1999).
} 
of later Indonesian resettlement policies that followed in the wake of military occupation as part of a wider campaign to distance the community from the subversive work of the guerilla resistance (Falintil).

The significance of this protracted history of displacement is not simply a distancing from food gardens, economic resources and some putative 'archive of past habitation and sociality' (Fairhead and Leach 1996:113), but very much a sense of separation from sites of economic livelihood, spiritual agency and moral authority (McWilliam 2007:173). Many Fataluku are keenly conscious of these processes of separation and attempt to overcome their loosening hold through active practices of re-engagement with ancestral sites and the manifold resources they contain. For the most part however, this has not led to a resettlement of ancestral places and arable lands, as the distance from markets, schools and other services as well as existing built investments, now make such a move for the majority, improbable and undesirable. Nevertheless, the significance of these lineage-based, ancestral land attachments remain a vital source of household and community identity and well being; an association that is sustained and reproduced through a range of strategic, practical and ritualised actions (McWilliam 2011).

\section{Fataluku land attachments}

There are multiple ways of appreciating Fataluku attachments to the deep forests and coasts of the Park area. For the purposes of illustration I would highlight two general domains of activity that provide some of the lived enactments of these Fataluku connections to their natural resources. The first and very prominent activity in which most people engage, is the gathering and harvesting of various wild growing foods that help sustain people's livelihoods and provide important and regular supplements to the seasonal harvesting of maize and other food staples cropped in nearby food gardens. In this regard there are multiple food resources available, from hunted game (especially deer, pigs, possums, monkeys, bats and snakes) and harvested marine foods (fish, shellfish, sea snakes, sea worms (meci), river shrimp, sea turtles, ${ }^{8}$ turtle eggs), as well as seaweeds and the diverse marine species collected through evening practices of reef gleaning. The hunting of game also forms part of a ritualised corpus of practices associated with harvesting the natural bounty of the land, including the gathering in of staple grain crops, the production of distilled palm liquor or seasonal harvesting of fish aggregations (api lere) and other living marine food (e.g. meci, Eunice virides) (see Palmer and Carvahlo 2008).

The forest and its rich tropical plant growth also provide a whole range of tubers, fruits, leafy vegetables, wild honey, gums, resins, timber, rope, thatch and rattan. Use is made of the multiple resources derived from the wild growing arenga palm which produces the distinctive black roof thatch of Fataluku traditional houses ( $f i a)$, as well as prodigious amounts of the milky syrup which is distilled into a strong clear liquor (tua haraki) and consumed with enthusiasm as a pastime and during ceremonial gatherings. The natural environment also provides a diverse pharmacology of plants, gums, fruits and barks that are widely used for their medicinal properties, and which are sought out as poultices for wounds and herbal remedies for all manner of identified illnesses (see McWilliam 2008). Medicinal plants represent a store of closely kept local knowledge with a deep experiential genealogy developed over generations of self reliance and self medication among Fataluku forest communities (see also Collins et al. 2007 for discussion of forest-based plant medicines used in Lautem to alleviate wounds and fevers among armed resistance fighters during the Indonesian military occupation when allopathic remedies were scarce). As a storehouse of food, the living environment of the national park ensures that Fataluku communities never suffer the draining privations of drought and food shortages experienced in other areas of Timor.

8 The coastal fringe of the NKSNP is a rich nesting ground for a range of sea turtle species that have been regularly captured and consumed. Turtle meat is smoked on racks over smouldering coals and savoured as a delicacy (see Edyvane et al. 2009). 
A second important realm of Fataluku attachment to the natural domain is the enduring significance of spiritual connections to ancestral and non-human spirit agencies. Fataluku ideas of spirit and potency are an esoteric and complex arena to which the following comments offer only brief reflections. Suffice to say that for all Fataluku communities residing within the boundary of the National Park, the living environment is always one where the agency of spirits and their often unobserved influence has a potentially powerful impact on everyday life. For these reasons the process of accessing and utilising the natural domain and drawing on its resources and protection, is one that needs to be approached with a degree of respect, caution and clear purpose. Fataluku describe the power of the spirit world with the generic term, téi which expresses a complex range of qualities associated with the sacred but also ideas of power, danger and dread. Places and forms that are marked as téi, (téinu pl.) are generally placated through invocatory prayers, sacrificial offerings and sometimes simple avoidance and in so doing people seek to reproduce a range of mutually beneficial ritual relationships (see also Pannell 2006; McWilliam 2011).

For the majority of resident Fataluku, key associations with the landscape are shaped by their membership to specific named clans or more specifically, paternally ordered origin groups and lineages known as Ratu. There are dozens of named Ratu in the region and their dispersed membership convenes periodically in commensal gatherings around marriages, funerals and other clan ceremonies to celebrate their ties to one another. It is through the mythologies and narrative traditions of ancestral settlements and their trajectory of place-making across the land that the customary claims of Ratu and their constituent households are founded. In a recent study, Raimundo Mau, who works within the National Directorate of Forestry responsible for coordinating the development of the National Park, has noted that all of the Park's land and resources are traditionally divided into these clan-centric claims of ownership and connection (2010:53-54,62). Group names such as Cailoro Ratu, Renu Ratu, Puitical Ratu, Aca Cao Ratu, Lavera Ratu, Pair Ratu, Konu Ratu, Kati Ratu, Marapaki, Latu Loho, Vacumura, Masipan, Serelao and Naza Ratu and many others, are linked through complex mythologies and oral histories of residence and other forms of tangible and intangible connections to bounded areas of land and resources within the Park. They represent the culmination of generations of settlement, warfare, alliance and mobility across the region.

An important element that sustains Fataluku Ratu agnatic groupings is the close attention to, and ritual communication with the ancestors of the house and clan - known generically as the calu ho papu ('grandfathers' and 'great-grandfathers'). ${ }^{9}$ All ceremonial and life cycle events for example are simultaneously an opportunity to 'feed' (fané) the ancestors and invoke their blessings, notwithstanding a general Fataluku orientation to Catholicism. Ancestral protections and blessings form part of an intrinsic set of approaches among most Fataluku to healing and warding off illness, seeking protective blessings against misfortune, and giving thanks for successful harvests and good fortune.

In these cases people make use of purpose-built household shrines, known as aca kaka or lafuru téi (sacred hearth). ${ }^{10}$ Most households maintain these separate structures which are derived from the paternal ancestors of the husband and are understood as an extension ultimately of the earliest origin hearth of the named clan. In this respect, house shrines represent the domestic expression of an extensive network of spatialised spiritual connections that link living members of the group with each other and to their ancestral origins (McWilliam 2011:12). Through sacrifice, prayer invocations and commensality at venerated places across the landscape, members of the group reproduce the memorialised record of ancestral settlement histories and their emplaced connections and entitlements.

\footnotetext{
9 Fataluku recognise at least 5 levels of upper generational agnates, Palu, Calu, Papu, Cuci and Macua [F, FF, FFF, FFFF, FFFFF]. These names may be publically known but beyond that they are said to be téi and may not be voiced. I have heard it said that the collective ancestral body may be referred to as the arafura.

10 The sacred hearth forms a separate boxed structure with sand and ash base on which are placed three hearth stones and several small forked sticks that are used in the cooking of sacrificial offerings and accompanying prayers.
} 
According to conventional Fataluku ideas, the efficacy and power of spirit agency increases as one moves away from the contemporary domestic space to more spatially, and hence, temporally distant sites of emplaced spirit. Here at various material markers of the ancestral presence - first landing sites, ancestral footsteps (ia mari tuliya), old graves (calu luturu) and abandoned settlements (lata paru), altar posts commemorating mythic events (ete uru hảa) or emplaced land spirits (téi/muacawa) - the enactment of ritual sacrifice engages a wider ancestral field and for this reason requires a higher level of ritual expertise to perform the necessary invocations. Within the boundaries of the park there are regular annual invocations undertaken at communal sites of origin to invoke the blessings of clan ancestors and participate in the commensal rituals of sociality that reconfirm group identity and solidarity. Thus, through the multiple, overlapping and criss-crossing network of connections to ritual sites across the memorialised Fataluku landscapes of the National Park, contemporary households and communities reproduce their cultural heritage through active performative engagements with their past. Collectively they provide exemplary illustrations of the kinds of perspectives highlighted in the complementary representations cultural heritage offered by Hoskins and Zerner.

\section{Park futures}

The cultural and economic significance of the National Park to contemporary Fataluku residents demonstrates in part some of the influential reasons why the decision was made to establish a multi-purpose conservation park. It is certainly the case that the formation of the park had its beginnings in part via the progressive environmental policies promoted and implemented during the Transitional Administration of the United Nations in East Timor [Untaet 1999-2002]. But the question remains to what extent the ideas and practices reproduced by local Fataluku in their everyday livelihoods and smallholder projects of economic engagement, can be accommodated in the management arrangements of the Park. Here things become rather less clear.

Table 1 shows the IUCN vision of what Conservation Parks might become. It demonstrates the shift that has occurred in the management of public reserves and conservation zones: one that moves from a top down people-averse system to more a participatory, people-inclusive model that acknowledges the multiple interests of stakeholder communities. The legislative framework for the Nino Konis Santana Park is very much consistent with this evolving appreciation of new ways to manage conservation.

Table 1. IUCN contrasting approaches to park organisation.

\begin{tabular}{|l|l|}
\hline Command Approach & Consultative Approach \\
\hline Planned and managed against people & Run with, and in some cases by local people \\
\hline Run by Central Government & Run by many partners \\
\hline Set aside for conservation & Run also with social and economic objectives \\
\hline Managed without regard to local community & Managed to help meet needs of local people \\
\hline Developed separately & Planned as part of national, regional and International systems \\
\hline Managed as islands & Developed as networks - strictly protected areas buffered and linked by green corridors \\
\hline Established mainly for scientific protection & Often set up for scientific, economic and cultural reasons \\
\hline Managed mainly for visitors and tourists & Managed with local people more in mind \\
\hline Managed reactively within short time frames & Managed adaptively with a long term perspective. \\
\hline About protection & Also about restoration and rehabilitation \\
\hline Viewed primarily as a national asset & Viewed as a community asset \\
\hline Viewed exclusively as a national concern & Viewed also as an international concern. \\
\hline
\end{tabular}

Source: Management Guidelines for IUCN Category V Protected Areas. Series 9, 2002:14. 
But while the decision of the Timor-Leste Government to promote this kind of park is certainly applauded, especially the inclusive participatory philosophy it expresses, the reality is that since its formal public declaration in 2008, very little has happened in terms of the organisational development of the Park. The Park remains to a significant degree a work in progress, and little more than a 'paper park. ${ }^{\prime 11}$ Plans for the establishment of an advisory board and management committees, inter-governmental coordination and agreements on the official conservation zoning of the various multi-purpose uses of the Park, or indeed concerted and continuing research efforts and consultation with local communities remain at a very preliminary stage. ${ }^{12}$

The reasons for this inertia are not entirely clear but are likely to be related to competing development priorities in the fledgling nation which struggles to overcome widespread poverty. There is also a general lack of institutional capacity and insufficient funding allocated to the National Directorate of Forestry, the agency charged with overall supervision and coordination of the National Park. One might also add that there is a marked absence of any community demand for action on this front reflecting the general point that the momentum to establish the conservation zone derives from interests external to the Park environment itself. In this sense one can speak of the Park as doubly imagined, a concept that still really only exists on paper as a symbolic commemoration of history, and perhaps a well meaning gesture towards environmental conservation and the economic possibilities that might develop in its wake.

A second issue that remains largely unresolved in terms of park management, is the question of formal rights and entitlements of communities with claims and connections to areas within the conservation zone. This is especially relevant to land ownership and the division of tenure rights between the State and local Fataluku groups who assert forms of customary attachment. The question is complicated by chronic delays in the formal acceptance of a national land law which will provide the necessary legal clarity and definitive regulatory framework for establishing entitlements to land. The decision to delay the current iteration of the new draft law until after the 2012 National Elections only extends that uncertainty into the future. ${ }^{13}$ But it means that, in this context, opportunities for local Fataluku households and communities to assert claims over customarily held lands are very much constrained (see also McWilliam 2007). While in most cases, cultivated land around existing settlements and residential land is likely to be recognised and converted into clear legal entitlements, this is by no means clear for the unsettled former ancestral lands in the distant canopy forest areas, much of which is still designated as a 'Wild Protected Area' under former UNTAET legislation with a range of restrictive access and use provisions (McWilliam 2004; UNTAET Regulation19/2000). ${ }^{14}$

Government Land and Property (DTP) staff often draw a distinction between Lei ('law and legal entitlements') and Kultura ('cultural interests'). The former provides secure entitlements subject to compensation for loss and the various protections accorded legally constituted rights. The latter represents a weaker form of negotiable customary interests subject to public consultation that may or may not attract binding obligations. If history is any guide, 'cultural interests' (Kultura) and related customary claims are often unsuccessful in the face of state regulatory simplifications,

\footnotetext{
11 The IUCN popularised the phrase 'paper park', which is generally held to be a largely unmanaged protected area or one where the threat of degradation continues unabated (IUCN 1999). http://www.worldwildlife.org/what/globalmarkets/forests/ WWFBinaryitem7370.pdf [accessed: 29/4/12].

12 An exception to this general statement is the thesis of Raimundo Mau (2010) who has developed a detailed zonation model for the Nino Konis Santana Park that seeks to address the different and overlapping environmental and community values of the region.

13 In February 2012, The President of Timor-Leste, Jose Ramos Horta, vetoed the passage of the parliamentary land law legislation on equity grounds.

14 My understanding is that the process of zoning within the broader boundaries of the Park will eventually supercede the need for retaining the Wild Protected Area legislation.
} 
which, as Zerner has observed, often work to deny or subsume any formal relation between what he calls the performative modalities of custom and the tightly scripted letter of the law. The ascription of Kultura in this context can also be read as a devaluation of the authority of local heritage in the face of the rigorous historical determinants of law authorised by the state.

That being the case, one sense of the prospective directions that might be taken by the government in this regard can be read in one of the articles (Chapter V) of the 2012 iteration of the draft National Land Law. ${ }^{15}$ Article 24 makes provision for two categories of recognition for community based land ownership; namely, Community Protection Zones and Community Property. The expressed purpose of these provisions is to safeguard the common interests of local communities and the lands and natural resources on which they depend. Drawing on elements of Mozambique land law, the category of community protection is specifically designed to avoid land speculation or unscrupulous economic activity by third parties, and is meant to ensure that significant development is always preceded by consultations that work to the benefit of the local community. According to the wording of the draft, the provision is intended to respect gender equity and 'socio-cultural sustainability' in use of natural resources. Importantly the provision also allows privatised titles of land within the boundary of the community protection zone to remain unaffected.

The second possibility of a Community Property provision may be even more significant. Under the draft law the definition of this category of land title refers to any immovable property which is of common and shared use. Potentially, the customary community in this case could secure an ownership title of the collective ancestral property, issued in its name, which thenceforth would be inalienable and unseizable (Draft Law footnote 7).

These progressive provisions within the draft land law indicate that lawmakers and politicians in Timor-Leste may be willing to go some way in recognizing customary claims and connections to ancestral lands that persist in varying degrees among local communities. The provisions would certainly accommodate and provide a much stronger legal protection to the kinds of cultural heritage practices and attachments that are sustained among Fataluku ritual communities within the Nino Konis Santana National Park. What remains unclear in these draft provisions is how they might work in practice and whether in fact they will ever be implemented in law. In a recent World Bank options paper, Fitzpatrick (2010) has provided a detailed analysis of the implications and unspoken complications inferred by the provisions of article 24, highlighting a range of risks and pitfalls of regulation, not the least of which include the potential for communal disputes and disenfranchisement, definitional problems and governmental capacity to oversee the process (see also Fitzpatrick et al. 2012). As Dove has observed in a commentary on the vulnerability of forest communities: ' $\mathrm{t}$ ] he problem is not that (they) are poor in resources ... but that they are politically weak; and the problem is not that the forest is environmentally fragile, but that it is politically marginal' (2012:191). The comparatively low and declining population numbers within the NKSNP, make this relation even more problematic.

For the majority of Fataluku households and communities resident within the National Park broader issues of park management remain secondary to the task of securing everyday livelihoods and the maintenance of social obligations. Reproduction of these relationships including the religious anchoring of ancestral blessings will continue to inform Fataluku decision making and orientation towards the region now encompassed within the National Park. The challenge, for the Timorese government is to find practical and supportive ways to accommodate the living cultural heritage values of locally resident Fataluku communities within a governance framework

15 See Draft Land Law Version 3, http://timorlestelandlaw.blogspot.com/2010/02/timor-leste-draft-law-for-special.html If the law is ever ratified it is likely that there would need to be an implementing regulation covering its application (see Fitzpatrick 2010:1). 
for the conservation of environmental values and its significance as a commemorative symbol of nationalism and the resistance struggle. Five years after the legislative creation of the Park, this remains the pressing challenge.

\section{Acknowledgements}

Fieldwork in East Timor has been made possible over a number of visits under the auspices of The Australian National University and an Australian Research Council Grant entitled "Waiting for law, land, custom and legal regulation in East Timor". I extend my appreciation to Timorese colleagues and numerous local Fataluku advisors for their assistance and generosity. I also wish to thank two anonymous reviewers for critical comment and suggestions on the paper.

\section{References}

Budiarjo, C. and Liem S.L. 1984. The war against East Timor.Zed Books, London.

Cardoso, J. 1933. Notas Florestais de Colónia de Timor. Boletim Geral das Colónias 9.

Collins, S. X., Martins, A., Mitchell, A., Teshome and Arnason, J. 2007. Fataluku medicinal ethnobotany and the East Timorese military resistance. Journal of Ethnobiology and Ethnomedicine 3(5).

De Silva, H.L.E. 1956. Timor e o cultura do cafe. Memórias Série de Agronomia Tropical I, Ministerios do Ultramar.

Dove, M. 2012. A political-ecological heritage of resource contest and conflict. In: Daly, P. and Winter, E. (eds), Routledge Handbook of Heritage in Asia, pp. 182-198. Routledge, London.

Edyvane, K., McWilliam, A., Quintas, J., Turner, A., Penny, S., Teixeira, I., Pereira, C., Tibirica, Y. and Birtles, A. 2009. Coastal and marine ecotourism values, issues and opportunities on the north coast of Timor Leste - final report. Ministry of Agriculture and Fisheries, National Directorate of Tourism, Government of Timor Leste.

Fairhead, J. and Leach, M. 1996. Misreading the African landscape: Society and ecology in a forest-savanna mosaic. Cambridge University Press, Cambridge.

Fitzpatrick, D. 2010. Policy options for regulating community property and community protection zones in Timor-Leste, Draft Report, World Bank.

Fitzpatrick, D., McWilliam, A.R. and Barnes, S. 2012. Property and Social Resilience in Times of Conflict: Land, custom and law in East Timor. Ashgate, Farnham UK.

Harvey, D.C. 2001. Heritage pasts and heritage presents: temporality, meaning and the scope of heritage studies. International Journal of Heritage Studies 7(4):319-338.

Hoskins, J. 1993. The play of time: Kodi perspectives on calendars, history and exchange. California University Press, California.

Hviding, E. and Bayliss-Smith, T. 2000. Islands of rainforest: Agro-forestry, logging and eco-tourism in Solomon Islands. Aldershot, Burlington.

IUCN. 1999. Threats to forest protected areas: Summary of a survey of 10 countries. A research report from IUCN The World Conservation Union for the World Bank/WWF Alliance for Forest Conservation and Sustainable Use. http://www.worldwildlife.org/what/globalmarkets/forests/ WWFBinaryitem7370.pdf [accessed: 29/4/12].

Li, T.M. (ed.) 1999. Transforming the Indonesian Uplands:Marginality, power and production. Harwood Academic Publishers, Singapore. 
Lowenthal, D. 1985. The past is a foreign country. Cambridge University Press, Cambridge.

Lowenthal, D. 1986. Fabricating heritage. History and Memory 10(1):5-24.

McWilliam, A. R. 2003. New beginnings in East Timor forestry management. Journal of Southeast Asian Studies 34(2)307-327.

McWilliam, A. R. 2006. Fataluku forest tenures and the Conis Santana National Park (East Timor). In: Reuter, T. (ed.), Sharing the earth, dividing the land: Territorial categories and institutions in the Austronesian world, pp.253-75. ANU E-Press, Canberra.

McWilliam, A. R. 2007. Customary claims and the public interest: On Fataluku resource entitlements in Lautem. In: Kingsbury, D. and Leach, M. (eds), East Timor: Beyond independence, pp.168-75. Monash Asia Institute Press, Melbourne.

McWilliam, A. R. 2008. Fataluku healing and cultural resilience in East Timor. Ethnos 73(2): 217-240.

McWilliam, A. R. 2011. Fataluku living landscapes. In: McWilliam A. R. and Traube, E.G. (eds), Land and life in Timor Leste: Ethnographic Essays, pp.61-86. ANU E-Press, Canberra.

MAFF. 2006. Draft proposal for Declaration Nino Konis Santana National Park. Ministry of Agriculture Forestry and Fisheries, Timor-Leste.

Mau, R. 2010. Ecosystem and community based model for Zonation in Nino Konis Santana National Park, Timor-Leste. Unpublished thesis, Institute Pertanian Bogor.

O'Connor, S. 2003. Nine new painted rock art sites from East Timor in the context of the Western Pacific region. Asian Perspectives 42:96-128.

O'Connor, S. and Pannell, S. 2006. Cultural heritage and the Nino Conis Santana National Park, Timor Leste: A preliminary survey. Unpublished manuscript.

Pannell, S. 2006. Welcome to the Hotel Tutuala: Fataluku accounts of going places in an immobile world. The Asia Pacific Journal of Anthropology 7(3)203-219.

Pannell, S. and O'Connor, S. 2005. Toward a cultural topography of cave use in East Timor: A preliminary study. Asian Perspectives 44(1):193-206.

Palmer, L. and de Carvalho, D. 2008. National building and resource management: The politics of nature in Timor Leste. Geoforum 39:1321-1332.

Scott, J. C. 1998. Seeing like a State: How certain schemes to improve the human condition have failed. Yale University Press, New Haven.

Zerner, C. A. 2003. Introduction - moving translations: poetics, performance and property in Indonesian and Malaysia. In: Zerner, C. (ed.), Culture and the question of rights: forests, coasts and seas in Southeast Asia, pp. 1-23. Duke University Press, Durham. 